\title{
Evidence of ontogenetic migration from mangroves to coral reefs by black-tail snapper Lutjanus fulvus: stable isotope approach
}

\author{
Yohei Nakamura ${ }^{1, *}$, Masahiro Horinouchi ${ }^{3}$, Takuro Shibuno ${ }^{4}$, Yoshiyuki Tanaka ${ }^{2}$, \\ Toshihiro Miyajima ${ }^{2}$, Isao Koike ${ }^{2}$, Hisashi Kurokura ${ }^{5}$, Mitsuhiko Sano ${ }^{5}$ \\ ${ }^{1}$ Department of Living Marine Resources, and ${ }^{2}$ Department of Chemical Oceanography, Ocean Research Institute, \\ The University of Tokyo, 1-15-1 Minamidai, Nakano-ku, Tokyo 164-8639, Japan \\ ${ }^{3}$ Research Center for Coastal Lagoon Environments, Shimane University, 1060 Nishikawatsu-cho, Matsue, Shimane 690-8504, \\ Japan \\ ${ }^{4}$ Ishigaki Tropical Station, Seikai National Fisheries Research Institute, 148-446, Fukai-Ohta, Ishigaki, Okinawa 907-0451, \\ Japan \\ ${ }^{5}$ Department of Global Agricultural Sciences, Graduate School of Agricultural and Life Sciences, The University of Tokyo, \\ 1-1-1 Yayoi, Bunkyo-ku, Tokyo 113-8657, Japan
}

\begin{abstract}
Mangroves are often considered to be important nurseries for coral reef fishes, yet this assumption has rarely been tested. At Ishigaki Island, southern Japan, black-tail snapper Lutjanus fulvus juveniles often occur in mangroves, whereas subadults and adults are usually found on coral reefs. To test the hypothesis that L. fulvus uses mangroves as a nursery, we conducted stomach content and stable isotope analyses of $L$. fulvus collected from mangroves and an adjacent coral reef. Stomach content analysis showed that specimens from mangroves fed on mangrove-associated prey, whereas those from the coral reef took coral reef-associated prey, indicating that the species undergoes ontogenetic changes in resource use from the mangroves to the coral reef, i.e. coral reef individuals did not migrate to the mangroves to feed. Stable isotope analysis showed that potential prey and mangrove red snapper L. argentimaculatus (control fish for mangroves) collected from the mangroves had ${ }^{13} \mathrm{C}$-depleted values of -23 to $-17 \%$, distinct from the -16 to $-8 \%$ values of potential prey and humpback red snapper L. gibbus (control fish for coral reef) collected from the coral reef. $\delta^{13} \mathrm{C}$ values of $L$. fulvus in the mangroves had a mangrove signature, whereas individuals on the coral reef gradually shifted from a mangrove signature to a coral reef signature with growth, indicating that small individuals on the coral reef were recent migrants from the mangroves. Based on the $\delta^{13} \mathrm{C}$ values of the subadult population of L. fulvus on the coral reef, 36 of 41 individuals were estimated to have inhabited the mangroves during their juvenile stage, demonstrating that $L$. fulvus used the mangroves as a nursery.
\end{abstract}

KEY WORDS: Mangrove $\cdot$ Coral reef $\cdot$ Lutjanidae $\cdot$ Stable isotope analysis $\cdot$ Ontogenetic habitat shift

\section{INTRODUCTION}

Assessing connectivity among populations of marine organisms is vital for understanding population dynamics, managing fisheries stocks, and designing marine protected areas. Many ecologically and commercially important marine organisms have life histories in which juvenile stages use different habitats than adults (Adams et al. 2006). Following Beck et al. (2001), a habitat is identified as a nursery for juveniles of a particular species if its contribution per unit area to the production of individuals that recruit to adult populations is greater, 
on average, than production from other habitats in which juveniles occur. Although several aquatic habitats, such as seagrass beds, marshes, and mangroves, have been frequently cited as nursery habitats, very few studies have addressed whether these juvenile habitats successfully transfer a higher juvenile biomass to the adult populations, thus being the vital missing link in our understanding of nurseries. This is largely due to the difficulty of tracking the movements of organisms between aquatic habitats and identifying the nursery habitats that adults have occupied.

A variety of artificial tagging methods have been used to determine movement from juvenile to adult habitats, although such traditional techniques pose difficulties because of the small size and high mortality rate of juveniles, and the large numbers that must be tagged in order to recover a sufficient sample size (Gillanders et al. 2003). Recently, the interpretation of biological markers such as isotopic and elemental composition has been used to determine connectivity between populations (e.g. Gillanders 2005, Herzka 2005). Stable isotopes can be used to trace the origin or movement of organisms, because isotopic signatures in animal tissues reflect those of local food webs or of the habitat in which they have grown (Hobson 1999). Several studies have used a variety of stable isotopes to investigate movements among habitats, including Fry et al. (1999), who examined $\delta^{13} \mathrm{C}$ values in tissues of pink shrimp Farfantepenaeus duorarum as they moved from inshore seagrass beds and mangrove-lined bays to offshore areas. Shrimps from seagrass beds had ${ }^{13} \mathrm{C}$-enriched values that were distinct from the values of individuals from mangrove-lined bays. However, smaller individuals collected offshore had $\delta^{13} \mathrm{C}$ values typical of individuals in seagrass beds rather than mangrove-lined bays, suggesting that most pink shrimp had moved from seagrass beds to offshore regions.

Mangroves often cover extensive areas surrounding coral reefs and are considered to be important nurseries for coral reef fishes (Parrish 1989). This nursery concept is largely supported by the abundance of juveniles of common reef fish species within mangroves (e.g. Nagelkerken \& van de Velde 2002) and higher adult densities on coral reefs adjacent to mangroves than on coral reefs without adjacent mangroves (Nagelkerken et al. 2002, Halpern 2004, Mumby et al. 2004). Typically, juveniles will eventually move to a reef habitat at maturation, although this assumption has rarely been tested (but see Chittaro et al. 2004). In recent years, mangrove systems have been under stress due to inadequate management and their vulnerability to human-related activities (Valiela et al. 2001, Duke et al. 2007). Under such circumstances, an assessment of biological connectivity between mangroves and coral reefs is urgently required, being a basic requirement for effective management of tropical coastal ecosystems as well as regional fisheries resources (Sheridan \& Hays 2003, Adams et al. 2006).

Black-tail snapper Lutjanus fulvus are widely distributed along the coasts of the subtropical/tropical IndoPacific region and are an important component of reefbased fisheries (Allen 1985). At Ishigaki Island, southern Japan, Shibuno et al. (2008) found that juvenile L. fulvus (30 to $120 \mathrm{~mm}$ in total length, TL) predominantly occurred in mangrove estuaries but sometimes occurred over reef flats, while subadults and adults (>120 mm TL) inhabited coral reefs, based on a quantitative visual census across multiple habitats (mangrove estuary, sand area, seagrass bed, coral rubble area, branching coral area on the reef flat, and tabular coral area on the reef slope). During the daytime, L. fulvus swim actively within each habitat, while at night they are found around mangrove prop roots, rocks on river bottoms, or under corals. Although the distribution patterns of individuals of different sizes support an ontogenetic habitat shift in L. fulvus from mangroves to coral reefs, the former functioning as a nursery, direct evidence of population connectivity between the 2 habitats is still lacking. If $L$. fulvus exhibit a distinct a clear ontogenetic shift from mangroves to coral reefs, individuals feeding in each habitat must consume local prey. Moreover, if L. fulvus use the mangrove habitat as a nursery, the most recent migrants to coral reefs should have stable isotope ratio values typical of individuals in mangroves.

Accordingly, this study was designed to address the following questions, using an application of stomach content and stable isotope analyses: (1) Is there an ontogenetic shift in habitat use from mangroves to coral reefs in Lutjanus fulvus? (2) Does the mangrovebased food web have $\delta^{13} \mathrm{C}$ signatures that are distinct from the coral reef-based food web? (3) Do $\delta^{13} \mathrm{C}$ values of $L$. fulvus collected from coral reefs gradually shift from a mangrove signature to a coral reef signature? (4) Do L. fulvus use mangroves as a nursery? The stomach contents and isotopic signatures of several sizes of 2 other species of snappers, humpback red snapper L. gibbus and mangrove red snapper L. argentimaculatus, were also investigated (as habitat control fishes), the former residing on coral reefs during the juvenile and adult life stages (control species for coral reef habitat), and the latter inhabiting mangroves until the body length reaches around $300 \mathrm{~mm}$ TL (control species for mangrove habitat; Shibuno et al. 2008).

\section{MATERIALS AND METHODS}

Study site. The study was carried out on the Itona coast of Ishigaki Island, southern Ryukyu Islands $\left(24^{\circ} 29^{\prime} \mathrm{N}, 124^{\circ} 13^{\prime} \mathrm{E}\right.$; Fig. 1). Despite the high latitude, 
well developed fringing coral reefs and mangrove habitats are present at Ishigaki Island, due to the Kuroshio Warm Current, which flows along the Ryukyu Islands. The mangrove estuary habitat was located near the mouth of the Fukido River $(500 \mathrm{~m}$ long, 10 to $40 \mathrm{~m}$ width up to $300 \mathrm{~m}$ upstream of the river mouth, total water surface area ca. $15000 \mathrm{~m}^{2}$ ), where riverbanks were densely occupied by undisturbed mature mangrove trees, dominated by Rhizophora stylosa, Bruguiera gymnorrhiza, Kandelia candel, and Lumnitzera racemosa. Water depth in the center of the river mouth was 0.5 to $1 \mathrm{~m}$ at low tide (the deep channel was ca. $1.5 \mathrm{~m}$ ) and 1 to $2 \mathrm{~m}$ at high tide (average tidal range $50 \mathrm{~cm}$ ), with mangrove prop roots alternately inundated and partially exposed during the tidal cycle. The river mouth was $18 \mathrm{~m}$ wide and marked by an extensive shallow tidal flat stretching (water depth $60 \mathrm{~cm}$ at low tide) approximately $200 \mathrm{~m}$ seaward. The fringing reef ( 0.5 to $5 \mathrm{~m}$ depth) extended seaward for approximately $1 \mathrm{~km}$ from the Fukido River to the reef edge. Beyond the reef edge, the outer slope (reef front) was steeply inclined to a sandy floor (depth ca. 15 to $20 \mathrm{~m}$ ). The salinity in the Fukido River ranged from 25 (low tide) to 35 (high tide), while that in reef habitats ranged from 34 to 36 , and water temperatures ranged from $26^{\circ} \mathrm{C}$ (May) to $29^{\circ} \mathrm{C}$ (August) in each habitat.

Sample collection. Collection of fishes and potential food items took place from late May through early October in 2004, 2005, and 2006 in the Fukido River (mangrove estuary, hereafter mangroves) and an adjacent coral reef (inner-reef habitats and outer reef slope; Fig. 1). Fishes were collected using seine (mesh size $5 \mathrm{~mm}$ ) and gill nets (mesh size 20 and $35 \mathrm{~mm}$ ) for juveniles (< ca. $120 \mathrm{~mm}$ standard length, SL) and harpoons for young and adults (> ca. $120 \mathrm{~mm} \mathrm{SL}$ ). On the coral reef, most specimens of Lutjanus fulvus and L. gibbus were collected from inner-reef habitats, although large individuals ( $>200 \mathrm{~mm}$ SL) were collected from the outer reef slope. On the coral reef, potential food items were collected from live/dead corals and coral rubble in the inner-reef coral habitats and on the reef slope, whereas prey from the mangrove habitat were collected from under rocks/stones or mangrove prop roots. Epifaunal (e.g. crabs, shrimps) and infaunal invertebrates (e.g. errant polychaetes) were collected using a hand-net (net mesh $1 \mathrm{~mm}$ ) and a cylindrical core sampler (13 cm in diameter and $10 \mathrm{~cm}$ in height), respectively. Because juvenile L. gibbus were also collected around small coral patches in the seagrass bed, potential food items (crabs, shrimps, amphipods, and isopods) were also collected from the latter. All samples were immediately frozen after collection. In the laboratory, SLs of fishes were measured to the nearest $\mathrm{mm}$, and the stomachs were preserved in $10 \%$ formalin for subsequent analysis.

Stomach content analysis. Food items in the stomach contents of each fish specimen were identified to the lowest possible taxon. The percentage volume of each food item in the diet was visually estimated under a


Fig. 1. Study site. Dotted line indicates reef margin. Black circles, sampling site; shaded area, assumed juvenile habitat area for Lutjanus fulvus within the coral reef (see Table 4) 
binocular microscope. Food resource use was expressed as mean percentage composition of each item by volume, calculated by dividing the sum total of the individual volumetric percentages for the item by the number of specimens examined. Specimens with empty stomachs were excluded from the analysis.

Stable isotope analysis. Fish tissues and potential food items were dried at $60^{\circ} \mathrm{C}$ for 24 to $40 \mathrm{~h}$ to a constant weight and then ground to a fine powder. Fish white muscle tissue was used for isotope analysis because of its slow turnover rate, which should reflect the isotopic composition of food assimilated over periods of several weeks to months (Herzka 2005). Because of the small size of gammaridean amphipods, isopods, crabs (carapace width $<1 \mathrm{~cm}$ ), and shrimp juveniles, whole individuals were processed, with 4 to 10 individuals pooled to make a single sample. Larger specimens (1 to $2 \mathrm{~cm}$ ) were each treated as single samples. To eliminate lipid effects on muscle $\delta^{13} \mathrm{C}$ measurements, lipids were removed from all samples by adding $3 \mathrm{ml}$ of chloroform:methanol (2:1) and extracting for $3 \mathrm{~h}$. The mixture was then centrifuged $\left(4^{\circ} \mathrm{C}, 760 \times g\right.$ for $\left.10 \mathrm{~min}\right)$, the supernatant discarded, and the pellet dried in a vacuum desiccator for $1 \mathrm{~h}$. All samples (fish tissues and invertebrates) were then treated by fuming under $12 \mathrm{M} \mathrm{HCl}$ for $10 \mathrm{~h}$ to remove inorganic carbonates, and excess acid was subsequently removed in a vacuum desiccator with some pellets of $\mathrm{NaOH}$ for $3 \mathrm{~h}$. The samples were dried at $60^{\circ} \mathrm{C}$ before analysis. Carbon and nitrogen stable isotope compositions were measured with an elemental analyzer connected on-line to an isotoperatio mass spectrometer (Thermo-electron, FLASH EA-Conflo III-DELTA plus XP). Isotopic compositions of $\mathrm{C}$ and $\mathrm{N}$ were expressed in $\delta$ notation as \%o differences from an international standard (Vienna Pee Dee Belemnite for carbon, atmospheric $\mathrm{N}_{2}$ for nitrogen):

$$
\delta X=\left[\left(R_{\text {sample }}-R_{\text {standard }}\right) / R_{\text {standard }}\right] \times 10^{3}
$$

where $X$ is ${ }^{13} \mathrm{C}$ or ${ }^{15} \mathrm{~N}$, and $R$ is the corresponding ratio, i.e. ${ }^{13} \mathrm{C} /{ }^{12} \mathrm{C}$ or ${ }^{14} \mathrm{~N} /{ }^{15} \mathrm{~N}$. Average reproducibility of $\delta^{13} \mathrm{C}$ and $\delta^{15} \mathrm{~N}$ values was about $0.1 \%$.

Otolith analysis. To estimate the time required for an individual to complete the shift from an isotopic signature reflective of a mangrove habitat to one reflective of the prey available in the reef habitat, otolith analysis of Lutjanus fulvus was conducted for age determination. Left sagittal otoliths were removed from 80 individuals, mounted in epoxy, and then sectioned transversely (1 mm thick) using a Buehler Isomet lowspeed jewelry saw. Sections were mounted on glass slides with Crystalbond thermoplastic cement, and the transverse plane of both sides was ground with 400-600 grit wet-dry sand paper until they were
$0.05 \mathrm{~mm}$ thick. Type A alumina powder $(0.3 \mu \mathrm{m})$ and a Buehler polishing cloth were used for final otolith preparations. The otolith micro-increments were then observed under a microscope with reflected light, and opaque rings were counted using an online computer screen. In this study, otolith rings were considered to represent daily increments, following Szedlmayer (1998). Moreover, increment deposition was considered to have begun at the time of hatching, because incubation times of lutjanids are relatively short (Thresher 1984). Two independent counts were made on each otolith by the same reader, and counts that differed by no more than $10 \%$ were averaged (Szedlmayer \& Conti 1999).

Data analysis. To assess whether dietary and isotopic changes occurred in Lutjanus fulvus in response to an ontogenetic habitat shift, individuals were sorted into 6 main size categories: (1) small juveniles in mangroves (42-73 mm SL), (2) large juveniles in mangroves (75-110, and $125 \mathrm{~mm} \mathrm{SL})$, (3) large juveniles on the coral reef (86-119 mm SL), (4) young on the coral reef (120-149 mm SL), (5) small adults (150-179 mm SL) on the coral reef, and (6) large adults (180-205 mm SL) on the coral reef. The control species, L. gibbus and L. argentimaculatus, were sorted into 2 main size categories; small individuals (54-73 mm SL for L. gibbus and 66-92 mm SL for L. argentimaculatus), and large individuals (142-275 mm SL for L. gibbus and 120-189 mm SL for L. argentimaculatus).

Biplots of $\delta^{13} \mathrm{C}$ and $\delta^{15} \mathrm{~N}$ values were used to examine the proximity of fish from different habitat types to potential source signatures. The main focus was on $\delta^{13} \mathrm{C}$ because the carbon baseline isotopic signatures differ among habitats, and $\delta^{13} \mathrm{C}$ signatures of consumers closely follow source values (e.g. Fry et al. 1999). Carbon isotope ratio values of fishes and prey animals in each month and year did not differ significantly ( $t$-test or analysis of variance [ANOVA], p > 0.05), enabling data for all sampling events to be combined. Mean values for $\delta^{13} \mathrm{C}$ values were compared among ontogenetic stages of the 3 lutjanid species by a Tukey-Kramer multiple comparison test. All data were $\log (x)$ transformed to improve homogeneity of variances.

To evaluate whether mangroves serve as a nursery habitat for Lutjanus fulvus on the Itona coast, the carbon isotopic signatures of large juveniles and young (hereafter, subadult) L. fulvus on the reef were examined. Here, we followed the nursery-role hypothesis of Beck et al. (2001): a nursery is a habitat for a particular species that contributes a greater than average number of individuals to the adult population on a per-unit area basis in comparison to other habitats used by juveniles. In this study, 'contribution' indicated the percentage of $L$. fulvus juveniles enter- 
ing the subadult population on the reef. The adult population (>150 $\mathrm{mm} \mathrm{SL})$ on the reef was not included in this analysis because all of the latter had reached isotopic equilibrium with the reef signatures, i.e. it was impossible to determine whether L. fulvus had migrated from the mangroves or grown on the reef. 'Area of mangroves' represented the total water surface area of the Fukido River and that of the coral reef represented by the inner-reef area on the Itona coast (Fig. 1). 'Nursery habitat' indicated whether contribution/area for a habitat was greater than the average contribution/area for the mangroves and coral reef.

\section{RESULTS}

\section{Stomach contents of fishes}

Of 80 Lutjanus fulvus, 37 (46\%) contained food items within their stomachs (Table 1). Those caught in mangroves (42-100 mm SL analyzed) contained predominantly estuary-associated crabs and shrimps, including Metopograpsus thukuhar, Utica gracilipes and Gaetice spp. (13 of 23 individuals), and Alpheus spp., followed by small fishes, including Lutjanus sp. (25 mm TL) and Eviota spp. Individuals collected from the coral reef contained mainly coral reef-associated crabs, such as Xanthidae spp. (e.g. Chlorodiella cytherea; large juveniles, 1 of 4 individuals; young, 3 of 6 individuals; small adults, 1 of 3 individuals), and Galathea spp. Estuary-associated crabs were not observed in the stomach contents of the coral reef individuals.
Of 18 Lutjanus argentimaculatus individuals, 14 (78\%) contained food items (66-174 mm SL) (Table 1), with the major item being estuary-associated grapsid crabs (Metopograpsus spp. and M. thukuhar; all individuals in the small-size class and 6 of 8 individuals in the large-size class). Three large $L$. argentimaculatus had also fed on fishes, including Ophiocara sp. (65 mm TL) and L. monostigma (40 mm TL). All L. gibbus examined contained food items; small individuals (54-73 mm SL) consumed shrimps and isopods, whereas larger fish (142-275 mm SL) consumed predominantly coral reef-associated crabs, such as Xanthidae (e.g. Chlorodiella cytherea, Etisus sp., Liomera spp., and Pilumnus sp.; 11 out of 18 individuals) and Menaethius monoceros (3 individuals).

\section{Isotopic signatures of potential food items and fishes}

The $\delta^{13} \mathrm{C}$ values of potential food items collected in the mangrove habitat ranged between -23 and $-17 \%$, and those of food items from the coral reef ranged between -16 and $-8 \%$ (Fig. 2). Most invertebrate samples showed relatively uniform $\delta^{13} \mathrm{C}$ values within each taxon (Table 2). Pooled samples of each taxon (crabs, shrimps, and hermit crabs) from the mangroves exhibited significantly lower $\delta^{13} \mathrm{C}$ values compared to those from the coral reef ( $t$-test, $\mathrm{p}<0.05$; Fig. 2). The $\delta^{13} \mathrm{C}$ values of pooled samples of shrimps showed no differences between the coral reef and the seagrass bed ( $t$-test, $\mathrm{p}=0.79$ ).

The $\delta^{13} \mathrm{C}$ values of Lutjanus fulvus caught in the mangroves ranged from -23 to $-17 \%$, with no difference observed between the 42-73 and 75-125 mm SL size

Table 1. Size range, number of fish samples used for stable isotope analysis, and stomach content analysis for each species per habitat. Food items comprising mean percentage volume of food items of each species. Cr: crabs, Sh: shrimps, He: hermit crabs, Is: isopods, My: mysids, Gm: gammaridean amphipods, Fh: fishes, Pl: errant polychaetes, Op: ophiuroids, Bi: bivalves, Others: food items composing $<5 \%$ of the gut content volume

\begin{tabular}{|c|c|c|c|c|c|c|c|c|c|c|c|c|c|c|c|}
\hline \multirow[t]{2}{*}{ Species/habitat } & \multirow{2}{*}{\multicolumn{2}{|c|}{$\begin{array}{c}\text { Size class } \\
\text { Range }(\mathrm{mm}) \text { Symbol }\end{array}$}} & \multicolumn{2}{|c|}{ Samples analyzed } & \multirow[b]{2}{*}{$\mathrm{Cr}$} & \multirow[b]{2}{*}{$\mathrm{Sh}$} & \multirow[b]{2}{*}{$\mathrm{He}$} & \multirow[b]{2}{*}{ Is } & \multicolumn{3}{|c|}{ - Food items (\%) } & \multirow{2}{*}{$\mathrm{Pl}$} & \multirow[b]{2}{*}{ Op } & \multirow[b]{2}{*}{$\mathrm{Bi}$} & \multirow[b]{2}{*}{ Others } \\
\hline & & & Isotopes & Stomachs & & & & & My & $\mathrm{Gm}$ & $\mathrm{Fh}$ & & & & \\
\hline \multicolumn{16}{|l|}{ Lutjanus fulvus } \\
\hline \multirow[t]{2}{*}{ Mangrove } & $42-73$ & $\mathrm{a}$ & 18 & 18 & 60 & 13 & & & & 10 & 16 & & & & 1 \\
\hline & $75-125$ & $\mathrm{~b}$ & 12 & 5 & 73 & 27 & & & & & & & & & \\
\hline \multirow{4}{*}{ Coral reef } & $86-119$ & $\mathrm{C}$ & 11 & 4 & 50 & & 25 & & & & & 13 & & & 12 \\
\hline & $120-149$ & d & 30 & 6 & 67 & 5 & 17 & 5 & & & & 6 & & & \\
\hline & $150-179$ & $\mathrm{e}$ & 6 & 3 & 76 & & 7 & & 17 & & & & & & \\
\hline & $180-205$ & $\mathrm{f}$ & 3 & 1 & & 80 & 20 & & & & & & & & \\
\hline \multicolumn{16}{|l|}{ Lutjanus gibbus } \\
\hline \multirow[t]{2}{*}{ Coral reef } & 54,73 & g & 2 & 2 & & 50 & & 50 & & & & & & & \\
\hline & $142-275$ & $\mathrm{~h}$ & 18 & 18 & 35 & 7 & 11 & & & & 6 & 20 & 9 & 8 & 4 \\
\hline \multicolumn{16}{|c|}{ Lutjanus argentimaculatus } \\
\hline \multirow[t]{2}{*}{ Mangrove } & $66-92$ & $\mathrm{i}$ & 7 & 6 & 100 & & & & & & & & & & \\
\hline & $120-189$ & j & 11 & 8 & 66 & 13 & & & & & 20 & & & & 1 \\
\hline
\end{tabular}




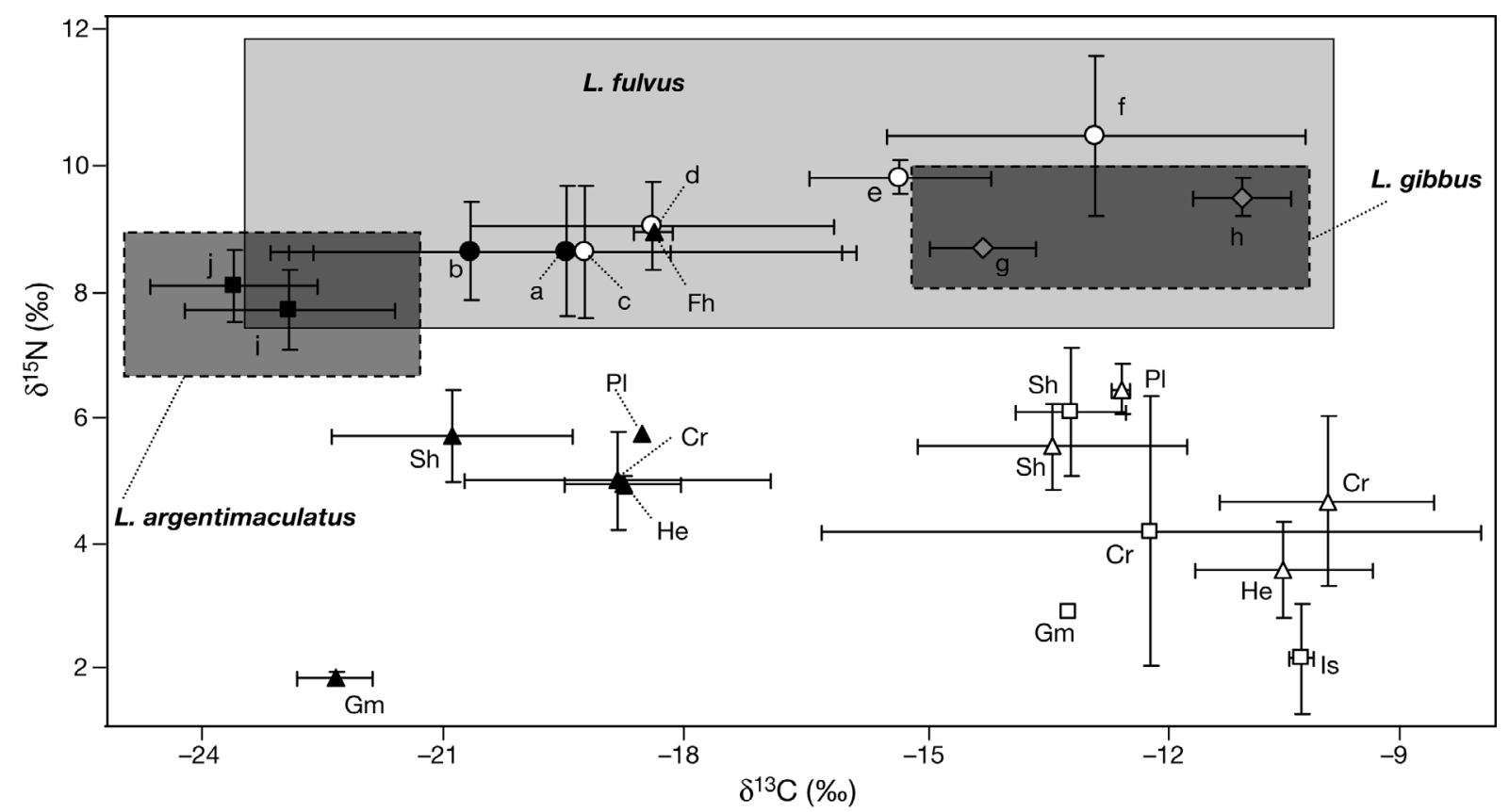

Fig. 2. Mean $( \pm \mathrm{SD}) \delta^{13} \mathrm{C}$ and $\delta^{15} \mathrm{~N}$ values of Lutjanus fulvus, L. gibbus, and L. argentimaculatus and their potential prey, collected from the mangroves $(\boldsymbol{\Delta})$, coral reef $(\Delta)$, and seagrass bed $(\square)$. Abbreviations and alphabetical symbols, see Table 1

classes (Table 3). L. fulvus collected from the coral reef (86-205 mm SL), on the other hand, showed increasingly enriched $\delta^{13} \mathrm{C}$ values with an increase in fish size class (Fig. 2), the latter ranging from -23 to $-11 \%$. Whereas the $\delta^{13} \mathrm{C}$ values of the 86-119 and $120-149 \mathrm{~mm}$ SL size classes were similar to those of individuals collected from the mangroves $(42-125 \mathrm{~mm} \mathrm{SL}$; $<-16 \%$ ), they were significantly lower than those of the $180-205 \mathrm{~mm}$ SL size class $\left(-16\right.$ to $-11 \%$ ). L. gibbus $\delta^{13} \mathrm{C}$ values ranged from -15 to $-14 \%$ for the small size class ( $54-73 \mathrm{~mm} \mathrm{SL})$ and -12 to $-10 \%$ for the large size class (142-275 mm SL), values similar to those of the large adult individuals of L. fulvus (Fig. 2, Table 3). The $\delta^{13} \mathrm{C}$ values of $L$. argentimaculatus ranged between -25 and $-22 \%$ (66-189 mm SL; Fig. 2), which were marginally lower than those of $L$. fulvus from the mangroves (Table 3). All Lutjanus species had $\delta^{15} \mathrm{~N}$ values enriched by approximately 3 to $5 \%$ over those of prey items, indicating that the former fed on prey caught in the same habitat (Fig. 2).

Fig. 3 shows the relationship between $\delta^{13} \mathrm{C}$ values and SL of Lutjanus fulvus collected from the mangroves and coral reef. Individuals caught in the mangroves generally had $\delta^{13} \mathrm{C}$ values below $-16.3 \%$ (lowest $\delta^{13} \mathrm{C}$ value of prey samples on the coral reef), although 4 individuals $(52,53,55$, and $66 \mathrm{~mm} \mathrm{SL}$; square symbols in Fig. 3) had markedly high $\delta^{13} \mathrm{C}$ values $(-15$ to $-13 \%)$. On the other hand, individual fish collected from the coral reef showed increasingly enriched $\delta^{13} \mathrm{C}$ values with an increase in fish size, from
$-16 \%$ for most individuals $<150 \mathrm{~mm}$ SL to over $-16 \%$ (highest value of prey samples in the mangroves) in individuals $>150 \mathrm{~mm}$ SL. Three individuals had very high $\delta^{13} \mathrm{C}$ values ( -15 to $-13 \%$ ) even though they were juveniles (86, 98, and $100 \mathrm{~mm} \mathrm{SL}$; see Fig. 3).

\section{Otolith analysis of Lutjanus fulvus}

Daily otolith increments of Lutjanus fulvus were usually difficult to interpret for specimens over $500 \mathrm{~d}$ old (ca. $150 \mathrm{~mm} \mathrm{SL}$ ). Moreover, isotopic analysis showed that all $L$. fulvus had carbon isotope ratio values typical of the coral reef when their body length reached around $150 \mathrm{~mm}$ SL. Therefore, individuals < ca. $152 \mathrm{~mm}$ SL were subjected to otolith analysis in order to estimate the time required for an individual to reach isotopic equilibrium with the food resources available on the coral reef after migrating from the mangrove habitat. Otoliths from 61 of 80 individuals collected were sufficiently clear for interpretation and analysis.

Fig. 4 shows the relationship between age and SL of 61 Lutjanus fulvus individuals collected from the mangroves and coral reef. The largest individuals collected from the mangroves were about 80 to $90 \mathrm{~mm}$ SL and approximately 180 to $200 \mathrm{~d}$ old. The age of $150 \mathrm{~mm}$ SL specimens was estimated as ca. $500 \mathrm{~d}$ old, indicating that about $300 \mathrm{~d}$ were required for migrated individuals to reach equilibrium with the foods available in the coral reef habitat. 


\section{Identification of nursery habitat for Lutjanus fulvus}

Of the 30 Lutjanus fulvus individuals caught in the mangroves, 4 showed much higher $\delta^{13} \mathrm{C}$ values ( -15 to $-13 \%$ ) than the others (Fig. 3), suggesting that they had recently migrated from the coral reef. On the other hand, 3 juveniles (86, 98, and $100 \mathrm{~mm}$ SL) collected from the coral reef showed enriched $\delta^{13} \mathrm{C}$ signatures indicative of growth on the reef. Two young individuals (133 and $138 \mathrm{~mm}$ SL) had enriched $\delta^{13} \mathrm{C}$ signatures, but of equivocal status, i.e. the isotopic signatures were intermediate between a mangrove- and a coral reefbased food web. Of the large juvenile and young individuals of $L$. fulvus collected from the coral reef (subadults), at least 36 of 41 had a carbon isotopic signature $(<-16 \%)$ indicative of previous growth in the mangrove habitat. Because the coral reef area $\left(340000 \mathrm{~m}^{2}\right)$ covered $96 \%$ of the Itona coast and contributed a maximum of $12.2 \%$ (5 individuals) of juveniles to the subadult population on the reef, whereas the mangrove area (total water surface area of Fukido River) comprised $4 \%$ of the coast and contributed $87.8 \%$ of juveniles (36 individuals) to the subadult coral reef population, the mangroves can be classified as a nursery habitat (per-unit area contribution of mangroves $=22.0>$ mean of mangroves and coral reef $=11.1$; Table 4 ), following the definition of Beck et al. (2001).

\section{DISCUSSION}

On tropical coasts, mangroves often serve as important feeding grounds for fishes from adjacent habitats (Sheaves 2005). In the present study, stomach content analysis of Lutjanus fulvus showed that individuals in the mangroves fed predominantly on mangrove-associated crabs and shrimps, whereas
Table 2. Overview of stable isotope data (mean $\pm 1 \mathrm{SD}$ ) for prey samples

\begin{tabular}{|c|c|c|c|}
\hline Potential prey & $\delta^{13} \mathrm{C}$ & $\delta^{15} \mathrm{~N}$ & $\mathrm{n}$ \\
\hline \multicolumn{4}{|l|}{ Mangroves } \\
\hline \multicolumn{4}{|l|}{ Crabs } \\
\hline Grapsidae spp. & $-19.0 \pm 1.4$ & $5.0 \pm 0.9$ & 10 \\
\hline Xanthidae spp. & $-19.3 \pm 5.1$ & $4.9 \pm 0.0$ & 2 \\
\hline Portuninae spp. & $-17.3 \pm 0.7$ & $5.1 \pm 0.8$ & 3 \\
\hline Unidentified & $-20.1 \pm 0.8$ & $4.9 \pm 1.1$ & 2 \\
\hline \multicolumn{4}{|l|}{ Shrimps } \\
\hline Macrobrachium spp. & $-20.5 \pm 1.7$ & $6.2 \pm 1.5$ & 3 \\
\hline Palaemon spp. & $-22.0 \pm 1.3$ & $5.6 \pm 0.4$ & 7 \\
\hline Alpheopsis spp. & $-19.8 \pm 0.8$ & $5.5 \pm 0.5$ & 6 \\
\hline \multicolumn{4}{|l|}{ Hermit crabs } \\
\hline Diogenidae spp. & $-18.8 \pm 0.7$ & $4.9 \pm 0.2$ & 4 \\
\hline Errant polychaetes & -18.6 & 5.7 & 1 \\
\hline Gammaridean amphipods & $-22.4 \pm 0.5$ & $1.8 \pm 0.1$ & 2 \\
\hline \multicolumn{4}{|l|}{ Fishes } \\
\hline Eviota spp. & $-18.4 \pm 0.2$ & $8.9 \pm 0.0$ & 2 \\
\hline \multicolumn{4}{|l|}{ Coral reef } \\
\hline \multicolumn{4}{|l|}{ Crabs } \\
\hline Trapezia spp. & $-10.8 \pm 1.0$ & $5.4 \pm 1.0$ & 18 \\
\hline Tetralia spp. & $-10.1 \pm 2.2$ & $5.5 \pm 0.7$ & 3 \\
\hline Cymo spp. & $-8.1 \pm 0.7$ & $3.0 \pm 0.8$ & 2 \\
\hline Xanthidae spp. & $-9.2 \pm 1.0$ & $3.4 \pm 1.1$ & 10 \\
\hline Unidentified & $-9.8 \pm 0.9$ & $3.9 \pm 0.2$ & 3 \\
\hline \multicolumn{4}{|l|}{ Shrimps } \\
\hline Palaemonidae spp. & $-12.8 \pm 1.0$ & $5.5 \pm 0.8$ & 4 \\
\hline Hippolytidae sp. & -16.0 & 5.5 & 1 \\
\hline \multicolumn{4}{|l|}{ Hermit-crabs } \\
\hline Galathea spp. & $-10.6 \pm 1.1$ & $3.5 \pm 0.8$ & 2 \\
\hline Errant polychaetes & $-12.6 \pm 0.1$ & $6.4 \pm 0.4$ & 3 \\
\hline Ophiuroids & $-3.6 \pm 0.6$ & $5.4 \pm 0.2$ & 4 \\
\hline \multicolumn{4}{|l|}{ Seagrass bed } \\
\hline \multicolumn{4}{|l|}{ Crabs } \\
\hline Unidentified & $-12.2 \pm 4.1$ & $4.1 \pm 2.2$ & 3 \\
\hline \multicolumn{4}{|l|}{ Shrimps } \\
\hline Leander spp. & $-13.3 \pm 0.8$ & $7.2 \pm 0.1$ & 2 \\
\hline Hippolyte spp. & $-13.9 \pm 0.8$ & $5.0 \pm 1.4$ & 2 \\
\hline Latreutes spp. & $-13.0 \pm 0.6$ & $6.0 \pm 0.6$ & 5 \\
\hline Gammaridean amphipods & -13.3 & 2.9 & 1 \\
\hline Isopods & $-10.4 \pm 0.2$ & $2.1 \pm 0.9$ & 2 \\
\hline
\end{tabular}

Table 3. Tukey-Kramer multiple comparison test between $\delta^{13} \mathrm{C}$ values of each size class of Lutjanus fulvus (a-f), L. gibbus ( $g$, h), and $L$. argentimaculatus $(i, j)$. For individual numbers in each size class of 3 lutjanid species, see Table 1 . Habitat: habitats in which collections were made, Mg: mangroves, Reef: coral reef, ns: $p>0.05$

\begin{tabular}{|c|c|c|c|c|c|c|c|c|c|c|c|c|}
\hline \multirow[t]{2}{*}{ Habitat } & \multicolumn{2}{|c|}{ Size class } & \multirow{2}{*}{$\bar{a}$} & \multirow[b]{2}{*}{$\mathrm{b}$} & \multicolumn{2}{|c|}{ - L. fulvus - } & \multirow[b]{2}{*}{ e } & \multirow[b]{2}{*}{$\mathrm{f}$} & \multicolumn{2}{|c|}{ L. gibbus } & \multicolumn{2}{|c|}{ L. argentimaculatus } \\
\hline & Range (mm) & Symbol & & & $\mathrm{C}$ & $\mathrm{d}$ & & & g & $\mathrm{h}$ & i & $\mathrm{j}$ \\
\hline $\mathrm{Mg}$ & $42-73$ & a & - & ns & ns & ns & $<0.05$ & $<0.01$ & ns & $<0.01$ & ns & $<0.01$ \\
\hline $\mathrm{Mg}$ & $75-125$ & $\mathrm{~b}$ & - & - & ns & ns & $<0.01$ & $<0.01$ & $<0.05$ & $<0.01$ & ns & ns \\
\hline Reef & $86-119$ & $\mathrm{C}$ & - & - & - & ns & ns & $<0.01$ & ns & $<0.01$ & ns & $<0.01$ \\
\hline Reef & $120-149$ & $\mathrm{~d}$ & - & - & - & - & ns & $<0.01$ & ns & $<0.01$ & $<0.01$ & $<0.01$ \\
\hline Reef & $150-179$ & $\mathrm{e}$ & - & - & - & - & - & ns & ns & $<0.01$ & $<0.01$ & $<0.01$ \\
\hline Reef & $180-205$ & $\mathrm{f}$ & - & - & - & - & - & - & $\mathrm{ns}$ & ns & $<0.01$ & $<0.01$ \\
\hline Reef & $54-73$ & g & - & - & - & - & - & - & - & ns & $<0.01$ & $<0.01$ \\
\hline Reef & $142-275$ & $\mathrm{~h}$ & - & - & - & - & - & - & - & - & $<0.01$ & $<0.01$ \\
\hline $\mathrm{Mg}$ & $66-92$ & i & - & - & - & - & - & - & - & - & - & ns \\
\hline
\end{tabular}




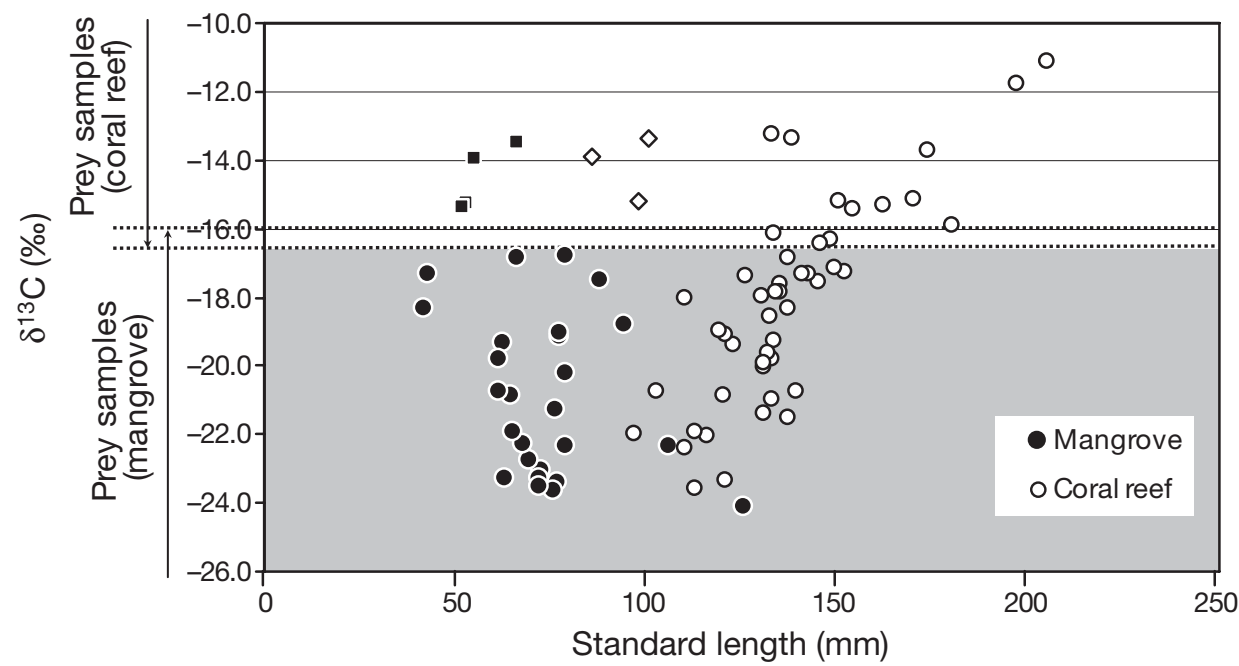

Fig. 3. Lutjanus fulvus. Relationship between $\delta^{13} \mathrm{C}$ values and standard length of individuals collected from the mangroves (black) and coral reef (white). Dotted horizontal bars indicate highest or lowest range of $\delta^{13} \mathrm{C}$ values of prey samples in the mangroves and on the coral reef, respectively. Shaded area shows typical range of $\delta^{13} \mathrm{C}$ values for mangrove prey samples. $\mathbf{\square}$, individuals with enriched $\delta^{13} \mathrm{C}$ values considered to be recent migrants from the coral reef; $\diamond$, individuals with enriched $\delta^{13} \mathrm{C}$ values indicative of growth on the coral reef

individuals on the coral reef fed mainly on coralassociated crabs. Moreover, L. fulvus $>100 \mathrm{~mm}$ SL were rarely observed in the mangroves during the study period (Shibuno et al. 2008). Given that juveniles exhibited a clear ontogenetic habitat shift from mangroves to coral reefs on the Itona coast, feeding migrations of $L$. fulvus into the mangrove habitat was unlikely. The migration patterns inferred from the isotopic data were therefore not confounded by shortterm feeding excursions. Stomach content analysis also showed that $L$. fulvus and $L$. argentimaculatus captured in the mangroves fed on fishes, including juvenile snappers. This indicates that lutjanids may themselves be piscivores targeting smaller fish sheltering and feeding in the mangroves, a common phenomenon in mangrove ecosystems (Sheaves 2001).

The $\delta^{13} \mathrm{C}$ values of potential food items from the mangroves, seagrass bed, and coral reef on the Itona coast were divisible into 2 groups: one associated with the mangroves (range, -23 to $-17 \%$ ), and the second associated with the seagrass bed $(-17$ to $-7 \%)$ and coral reef $\left(-16\right.$ to $-8 \%$ ). Similar $\delta^{13} \mathrm{C}$ gradients among habitats have been reported from other tropical coasts (Fry et al. 1982, Marguillier et al. 1997, Cocheret de la Morinière et al. 2003), indicating that carbon stable isotopes provided good discrimination between biota from mangroves and seagrass beds/coral reefs.

$\delta^{13} \mathrm{C}$ values of the control fish species reflected those of their respective habitats. Lutjanus gibbus had coral reef-based food web signatures ( -15 to $-10 \%$ ), whereas $L$. argentimaculatus had mangrove-based food web signatures ( -25 to $-22 \%$ ). $\delta^{13} \mathrm{C}$ values of $L$. fulvus collected from the mangroves also indicated mangrovebased food web signatures ( -23 to $-17 \%$ o), although slightly enriched compared to those of L. argentimaculatus. This difference might be explained by differences in the sampling localities of the 2 species in the mangroves. L. fulvus and potential prey were collected



Fig. 4. Lutjanus fulvus. Relationship between age and standard length of 61 individuals collected from the mangroves (black) and coral reef (white). Approximate logarithmic curve plotted 
Table 4. Determination of nursery habitat of Lutjanus fulvus. Contribution: percentage of juveniles entering the subadult population on the reef. Nursery habitat calculated by dividing contribution by area. Nursery habitat: contribution per area is greater than average contribution per area of overall ecosystem. Area of coral reef represented by inner reef area (see Fig. 1)

\begin{tabular}{|lcccc|}
\hline Habitat & $\begin{array}{c}\text { Contribution } \\
(\%)\end{array}$ & $\begin{array}{c}\text { Area } \\
(\%)\end{array}$ & $\begin{array}{c}\text { Contribution } \\
\text { per area }\end{array}$ & $\begin{array}{c}\text { Nursery } \\
\text { habitat }\end{array}$ \\
\hline Coral reef & 12.2 & 96 & 0.1 & NO \\
Mangroves & 87.8 & 4 & 22.0 & YES \\
Total & 100 & 100 & 22.1 & \\
Mean & 50 & 50 & 11.1 & \\
\hline
\end{tabular}

throughout the mangrove habitat, whereas L. argentimaculatus, especially larger individuals, were collected mainly from the deep channel located in the more upstream zone. Supporting evidence for this has been found in the $\delta^{13} \mathrm{C}$ values of invertebrates from upstream mangrove zones showing more depleted $\delta^{13} \mathrm{C}$ values than those from downstream zones (Chong et al. 2001). Large juveniles and young L. fulvus (86-149 mm SL) caught from the coral reef had a carbon isotopic signature characteristic of the mangrovebased food web, indicating that they had recently migrated from the mangroves. The ${ }^{13} \mathrm{C}$ signature of increasingly larger $L$. fulvus collected from the coral reef was increasingly enriched, suggesting a gradual shift in $\delta^{13} \mathrm{C}$ values from the mangrove-based food web to the coral reef-based food web corresponding with isotopic turnover. Large adult L. fulvus (>180 mm SL) had enriched $\delta^{13} \mathrm{C}$ values similar to those of L. gibbus, indicating that the former were close to reaching equilibrium in terms of $\delta^{13} \mathrm{C}$ with the coral reef-based food web.

A limited number of studies have estimated isotopic turnover rates for fishes (for review see Herzka 2005). Larvae and early juveniles, which are rapidly growing organisms, reach equilibrium relatively quickly, potentially losing their initial signature within days or weeks (e.g. Herzka \& Holt 2000), whereas older or larger fish may take well over 1 yr (e.g. Hesslein et al. 1993). Similarly, L. fulvus requires approximately $300 \mathrm{~d}$ for a complete turnover of muscle tissue carbon from the lowest mangrove signatures $\left(\delta^{13} \mathrm{C}=-24 \%\right)$ to the lowest coral reef signatures (-16\%; Figs. $3 \& 4)$.

Based on the carbon isotopic signature of subadult Lutjanus fulvus collected from the coral reef (Fig. 3) and the nursery definition of Beck et al. (2001), the mangroves rather than the coral reef can be classified as a nursery habitat (Table 4). However, in this study sampling on the reef was only performed on a small fraction of the reef habitats, so an important consideration is how representative subadult samples are of the entire subadult L. fulvus population. At Itona coast, we collected subadult L. fulvus from 2 inner-reef sites where the latter predominantly occurred. Therefore, the subadult samples collected from the reef might be well representative of the whole subadult $L$. fulvus population on the reef.

The pelagic larval duration of many lutjanid species is 3 to $4 \mathrm{wk}$ (Zapata \& Herrón 2002). The sagittal otoliths of Lutjanus fulvus exhibited comparable settlement marks (post-settlement increment widths were consistently narrower than those laid down before settlement). Because lutjanid larvae have been captured by light traps in the Fukido River (T. Shibuno unpubl. data), L. fulvus larvae may recruit to the mangrove area directly after their pelagic stage. However, because enriched ${ }^{13} \mathrm{C}$ signatures of some juveniles in the mangroves suggested that they were recent arrivals from the coral reef, the juvenile population of L. fulvus in the mangroves might therefore have 2 sources, one settling directly to the mangroves and the other migrating to mangroves from reef habitats during the benthic juvenile stage. Although the latter process may be minor and easily missed by underwater observers, it may be important in sustaining mangrove juvenile populations. Further evaluation of the biological connectivity between mangroves and coral reefs is needed. Overall, most L. fulvus juveniles were estimated as inhabiting mangroves for some 4 to 6 mo before migrating to adjacent coral reef habitats.

In conclusion, we confirmed population connectivity between the mangrove and coral reef habitats by ontogenetic migration of Lutjanus fulvus. Most L. fulvus inhabited the mangroves as a nursery for some 4 to 6 mo during their juvenile stage and then migrated to the adjacent coral reef. Such an ontogenetic migration between mangroves and coral reefs is crucial for sustaining coral reef fish populations, because the availability of mangrove nursery habitats strongly influences the assemblage structure and biomass of reef fishes in their adult coral reef habitats (Nagelkerken et al. 2002, Halpern 2004, Mumby et al. 2004). The worldwide declines of mangroves (Valiela et al. 2001) and coral reefs (Bellwood et al. 2004) and related resources call for an urgent reassessment of current management practices. Our findings support the application of management action for tropical coasts to areas of connected habitats, rather than simply identifying representative areas of each habitat in isolation (Mumby et al. 2004). However, we focused on a specific fish species within a relatively small spatial scale $(<2 \mathrm{~km})$. Clearly, further work is required to assess the biological connectivity between habitats with different spatial scales using several organisms, relevant to effective management plans for tropical coasts. 
Acknowledgements. We are grateful to Y. Takada, O. Abe, K. Hashimoto, M. Kobayashi, M. Sasaki, and the Seikai National Fisheries Research Institute for assistance in the fieldwork. We also thank $\mathrm{H}$. Yamada for assisting in otolith analysis. Constructive comments on the manuscript from G. Hardy and anonymous reviewers were much appreciated. This study was funded by a Grant-in-Aid for Scientific Research (B) from the Japan Society for the Promotion of Science (No. 16380127), and supported in part by the 'F-5 Study on the Selection of Biodiversity Conservation Areas of Coral Reefs (FY2003-FY2005)' by the Japanese Ministry of the Environment and the 21st Century COE Program of the University of the Ryukyus.

\section{LITERATURE CITED}

Adams AJ, Dahlgren CP, Kellison GT, Kendall MS and others (2006) Nursery function of tropical back-reef systems. Mar Ecol Prog Ser 318:287-301

Allen GR (1985) FAO species catalogue, Vol 6. Snappers of the world. An annotated and illustrated catalogue of lutjanid species known to date. FAO Fish Synop No. 125, Vol 6. FAO, Rome

Beck MW, Heck KL Jr, Able KW, Childers DL and others (2001) The identification, conservation, and management of estuarine and marine nurseries for fish and invertebrates. BioScience 51:633-641

Bellwood DR, Hughes TP, Folke C, Nyström M (2004) Confronting the coral reef crisis. Nature 429:827-833

Chittaro PM, Fryer BJ, Sale PF (2004) Discrimination of French grunts (Haemulon flavolineatum, Desmarest, 1823) from mangrove and coral reef habitats using otolith microchemistry. J Exp Mar Biol Ecol 308:169-183

Chong VC, Low CB, Ichikawa T (2001) Contribution of mangrove detritus to juvenile prawn nutrition: a dual stable isotope study in a Malaysian mangrove forest. Mar Biol 138:77-86

Cocheret de la Morinière E, Pollux BJA, Nagelkerken I, Hemminga MA, Huiskes AHL, van der Velde G (2003) Ontogenetic dietary changes of coral reef fishes in the mangrove-seagrass-reef continuum: stable isotopes and gut-content analysis. Mar Ecol Prog Ser 246:279-289

Duke NC, Meynecke JO, Dittmann S, Ellison AM and others (2007) A world without mangroves? Science 317: 41-42

Fry B, Lutes R, Northam M, Parker PL, Ogden J (1982) A ${ }^{13} \mathrm{C} /{ }^{12} \mathrm{C}$ comparison of food webs in Caribbean seagrass meadows and coral reefs. Aquat Bot 14:389-398

Fry B, Mumford PL, Robblee MB (1999) Stable isotope studies of pink shrimp (Farfantepenaeus duorarum Burkenroad) migrations on the southwestern Florida shelf. Bull Mar Sci 65:419-430

Gillanders BM (2005) Using elemental chemistry of fish otoliths to determine connectivity between estuarine and coastal habitats. Estuar Coast Shelf Sci 64:47-57

Gillanders BM, Able KW, Brown JA, Eggleston DB, Sheridan PF (2003) Evidence of connectivity between juvenile and adult habitats for mobile marine fauna: an important component of nurseries. Mar Ecol Prog Ser 247:281-295

Halpern BS (2004) Are mangroves a limiting resources for two coral reef fishes? Mar Ecol Prog Ser 272:93-98

Editorial responsibility: Howard Browman, Storebø, Norway
Herzka SZ (2005) Assessing connectivity of estuarine fishes based on stable isotope ratio analysis. Estuar Coast Shelf Sci 64:58-69

Herzka SZ, Holt GJ (2000) Changes in isotopic composition of red drum (Sciaenops ocellatus) larvae in response to dietary shifts: potential applications to settlement studies. Can J Fish Aquat Sci 57:137-147

Hesslein RH, Hallard KA, Ramlal P (1993) Replacement of sulfur, carbon, and nitrogen in tissue of growing broad whitefish (Coregonus nasus) in response to a change in diet traced by $\delta^{34} \mathrm{~S}, \delta^{13} \mathrm{C}$, and $\delta^{15} \mathrm{~N}$. Can J Fish Aquat Sci 50:2071-2076

Hobson KA (1999) Tracing origins and migration of wildlife using stable isotopes: a review. Oecologia 120:314-326

Marguillier S, van der Velde G, Dehairs F, Hemminga MA, Rajagopal S (1997) Trophic relationships in an interlinked mangrove-seagrass ecosystem as traced by $\delta^{13} \mathrm{C}$ and $\delta^{15} \mathrm{~N}$. Mar Ecol Prog Ser 151:115-121

Mumby PJ, Edwards AJ, Arias-Gonzalez JE, Lindeman KC and others (2004) Mangroves enhance the biomass of coral reef fish communities in the Caribbean. Nature 427: $533-536$

Nagelkerken I, van der Velde G (2002) Do non-estuarine mangroves harbour higher densities of juvenile fish than adjacent shallow-water and coral reef habitats in Curaçao (Netherlands Antilles)? Mar Ecol Prog Ser 245:191-204

Nagelkerken I, Roberts CM, van der Velde G, Dorenbosch M, van Riel MC, Cocheret de la Morinière E, Nienhuis PH (2002) How important are mangroves and seagrass beds for coral reef fish? The nursery hypothesis tested on an island scale. Mar Ecol Prog Ser 244:299-305

Parrish JD (1989) Fish communities of interacting shallowwater habitats in tropical oceanic regions. Mar Ecol Prog Ser 58:143-160

Sheaves M (2001) Are there really few piscivorous fishes in shallow estuarine habitats? Mar Ecol Prog Ser 222: 279-290

Sheaves M (2005) Nature and consequences of biological connectivity in mangrove systems. Mar Ecol Prog Ser 302: 293-305

Sheridan P, Hays C (2003) Are mangroves nursery habitat for transient fishes and decapods? Wetlands 23:449-458

Shibuno T, Nakamura Y, Horinouchi M, Sano M (2008) Habitat use patterns of fishes across the mangrove-seagrasscoral reef seascape at Ishigaki Island, southern Japan. Ichthyol Res doi: 10.1007/s10228-007-0022-1

Szedlmayer ST (1998) Comparison of growth rate and formation of otolith increments in age-0 red snapper. J Fish Biol 53:58-65

Szedlmayer ST, Conti J (1999) Nursery habitats, growth rates, and seasonality of age-0 red snapper, Lutjanus campechanus, in the northeast Gulf of Mexico. Fish Bull 97: 626-635

Thresher RE (1984) Reproduction in reef fishes. TFH Publ, Neptune City, NJ

Valiela I, Bowen JL, York JK (2001) Mangrove forests: one of the world's threatened major tropical environments. BioScience 51:807-815

Zapata FA, Herrón PA (2002) Pelagic larval duration and geographic distribution of tropical eastern Pacific snappers (Pisces: Lutjanidae). Mar Ecol Prog Ser 230:295-300

Submitted: April 25, 2007; Accepted: September 5, 2007

Proofs received from author(s): February 5, 2008 